\title{
Efekt placebo/nocebo prognozy lekarskiej
}

\author{
Adam Jonkisz', Katarzyna Szmaglińska', Monika Fajler ${ }^{1}$ \\ 1 Zakład Filozofii i Bioetyki, Katedra Nauk Społecznych i Humanistycznych, Wydział Nauk o Zdrowiu w Katowicach, Śląski \\ Uniwersytet Medyczny w Katowicach
}

Jonkisz A, Szmaglińska K, Fajler M. Efekt placebo/nocebo prognozy lekarskiej. Med Og Nauk Zdr. 2017; 23(1): 1-6. doi: 10.5604/20834543.1235618

\begin{abstract}
Streszczenie
Wprowadzenie. Efekt placebo/nocebo odnosi się do działania nieaktywnych farmakologicznie substancji podawanych w postaci recepturalnej (najczęściej tabletki), identycznej z tą, która zawiera substancje lecznicze i może być korzystny, obojętny lub niekorzystny dla chorego. Interdyscyplinarne badania tego efektu wskazują na rolę oczekiwań jako zjawisk psychobiologicznych, wyniki tych badań są istotne także dla etyki lekarskiej.

Cel pracy. Sformułowanie ważnych dla praktyki lekarskiej wniosków z wyników badań nad efektem placebo.

Skrócony opis stanu wiedzy. Wyniki badań empirycznych potwierdzają pogląd, iż procesy mentalne mogą aktywizować mechanizmy podobne do wywoływanych przez leki.

Podsumowanie. Wnioski: 1. Przekazywanie diagnozy i rokowania może powodować konflikt norm szacunku dla autonomii, nieszkodzenia i dobroczynności. 2. Stosowanie zalecanych w etykach zawodowych metod rozwiązywania konfliktów wartości i norm jest utrudnione, gdyż: pojęcie i kryteria dobra pacjenta są niejasne i nieostre; przyjęta przez WHO definicja zdrowia jest, z praktycznego punktu widzenia, za szeroka. 3. Wyniki badań klinicznych nad efektem nocebo, a także psychologicznych nad atrybucjami, potwierdzają, że prawda i norma prawdomówności nie są absolutne, czasem nieprzekazywanie pacjentowi całej prawdy jest usprawiedliwione - uwzględnia się to w postulatach dotyczących procedur informowania pacjenta (wykorzystanie możliwości niepoinformowania). 4. Dobra komunikacja może zmniejszyć negatywne skutki procedur medycznych i przekazywanych informacji - zwłaszcza diagnoz i rokowań skrajnie niekorzystnych. 5. Uwzględnienie efektu nocebo prognozy medycznej przemawia za poszukiwaniem zawodowo i etycznie akceptowalnych zaleceń (ścisłe procedury nie są możliwe) co do przekazywania pacjentom prognoz.
\end{abstract}

\section{Słowa kluczowe}

placebo, nocebo, konflikt wartości i norm, komunikacja z pacjentem, przekazywanie diagnozy i rokowania

\section{WPROWADZENIE}

Termin „placebo" jest używany w językach wielu dyscyplin. Interdyscyplinarność tego pojęcia nie ułatwia kwestii jego dobrego określenia. Jest to widoczne w publikacjach naukowych, w których są proponowane różne definicje "placebo", niektóre wzajemnie się wykluczające [1].

Spośród wielu znaczeń tego terminu podstawowe są trzy, tj. „placebo", rozumiane jako:

1) ,[...] jakakolwiek terapia lub jej element zastosowany w sposób zamierzony ze względu na jego niespecyficzny, psychologiczny lub psychofizjologiczny efekt, albo ze względu na jego przypuszczalny efekt specyficzny, ale bez specyficznego działania dla leczonego schorzenia" [1, s. 143];

2) stosowana dla celów porównawczych w kontrolowanych badaniach eksperymentalnych substancja lub procedura bez specyficznego działania dla badanego schorzenia;

3) niespecyficzny psychologiczny lub psychofizjologiczny efekt (pozytywny lub negatywny), wywoływany przez placebo rozumiane jako składnik terapii.

W każdej z powyższych definicji jest użyte (wprost bądź nie wprost) pojęcie efektu specyficznego/niespecyficznego. Najczęściej przyjmuje się, że efekt specyficzny to rezultat działania aktywnych składników terapii (np. właściwości farmakologicznych leku), a efekt niespecyficzny jest zależny

Adres do korespondencji: Adam Jonkisz, Śląski Uniwersytet Medyczny w Katowicach, Wydział Nauk o Zdrowiu w Katowicach, Katedra Nauk Społecznych i Humanistycznych, Zakład Filozofii i Bioetyki

E-mail:abjonkisz@gmail.com

Nadesłano: 22.10.2016; zaakceptowano do publikacji: 9.02.2017 od zmiennych towarzyszących (np. smaku, wielkości czy koloru tabletki) $[1,2,3]$. Ogólniej i używając innej terminologii, można powiedzieć, że efekty specyficzne to efekty działania składników terapii zależnych od terapeuty czy badacza (np. jakość i dawki podanego leku) oraz zastosowanych w celu osiągnięcia skutku terapeutycznego. Natomiast efekty niespecyficzne są skutkami składników lub cech (zmiennych) terapii, które nie są zamierzone jako terapeutyczne i które mogą być niezależne od terapeuty czy badacza.

Dla przedmiotu rozważań zawartych w tej pracy podstawowe jest trzecie z przytoczonych znaczeń terminu „placebo", tj. placebo rozumiane jako efekt terapii, które zakłada jednak pojęcie „placebo" jako składnika terapii. W kontekście "placebo", rozumianego jako efekt niespecyficzny został wprowadzony termin „nocebo" [4]. Termin ten odnosi się do sytuacji, gdy wskutek działania placebo (rozumianego jako składnik terapii) pogarsza się funkcjonowanie/samopoczucie osoby poddanej terapii. W kontekście przyjętych definicji jest oczywiste, że efekt nocebo podpada pod pojęcie „placebo", z tym że jest efektem dla pacjenta niekorzystnym (z tego powodu bywa nazywa odwróconym efektem placebo). Gdy więc w rozważaniach będzie potrzeba odróżniania efektu placebo korzystnego (placebo +) oraz niekorzystnego (placebo -), będą używane odpowiednio: węziej niż w definicji 3. rozumiany termin "placebo" oraz termin „nocebo". O efekcie nocebo mówi się np., gdy samo spodziewanie się przez leczonego negatywnych, niepożądanych skutków działania leku, terapii wywołuje niepożądane objawy lub gdy

1. Do węższego rozumienia placebo (placebo +) odsyła łacińskie placebo = spodobam się, przytoczona definicja placebo obejmuje jednak także efekty niekorzystne. 
negatywne nastawienie co do skutków leczenia zmniejsza skuteczność leku.

\section{CEL PRACY}

Celem głównym pracy jest sformułowanie ważnych dla praktyki lekarskiej wniosków z wyników badań nad efektem placebo. Dla sformułowania ich potrzebne są wyżej przyjęte ustalenia terminologiczne dotyczące pojęć „placebo” i „nocebo" oraz uwzględnienie nowych wyników badań naukowych nad tymi efektami.

\section{STAN WIEDZY W ZAKRESIE EFEKTU PLACEBO/ NOCEBO}

W wielu badaniach zostały potwierdzone pozytywne bądź negatywne skutki obojętnych interwencji dokonanych w trakcie przeprowadzania badań laboratoryjnych czy obserwacji kontrolowanej ${ }^{2}$. W. Hauser i in. opisują badanie, w którym 50 pacjentów cierpiących na chroniczny ból pleców podzielono losowo na dwie grupy: jednej powiedziano, że test sprawności, który wykonają, przyniesie pogorszenie odczuwanego bólu, drugiej zakomunikowano, że test nie zmieni stopnia odczuwanego bólu. Pacjenci z pierwszej grupy odczuwali i zgłaszali silniejsze odczucia bólu niż osoby z grupy drugiej: w skali 101-punktowej, uśrednione nasilenie bólu w grupie pierwszej wyniosło 48,1, a w grupie drugiej - 30,2 [5]. Z kolei w badaniach dotyczących pacjentów onkologicznych wykazano, że pacjenci poddawani chemioterapii oczekujący pojawienia się nudności, odczuwali je po leczeniu częściej niż ci, którzy byli pozytywnie lub obojętnie nastawieni do cytostatyków [6]. W innych badaniach (przeprowadzonych przez zespół kierowany przez F. Benedettiego), osobom cierpiącym na chorobę Parkinsona i poddawanym zabiegowi implantacji elektrod stymulujących mózg, parę razy przed zabiegiem podano apomorfiny; później badacze zastąpili ten lek placebo - okazało się, że osiągnięto skutki podobne do powodowanych przez apomorfinę (np. obniżenie sztywności mięśni). Efekt był wprawdzie krótkotrwały (20-30 minut), ale przydatny z klinicznego punktu widzenia, gdyż pacjent czuł się lepiej, a procedury operacyjne można było wykonać prościej i szybciej. Takie działanie może być przydatne zwłaszcza wtedy, gdy prawdziwy środek terapeutyczny ma wiele skutków ubocznych niekorzystnych dla zdrowia pacjenta $[7,8]$.

Międzynarodowy zespół badawczy ze Stanów Zjednoczonych i Kolumbii przeprowadził i opublikował w 2014 roku wyniki systematycznego przeglądu i metaanalizy badań dotyczących działania leków przeciwdepresyjnych u dzieci (6-12 lat) i młodzieży (13-18 lat) dotkniętych depresją. Badania, przeprowadzone $\mathrm{z}$ użyciem próby klinicznej i placebo, były podwójnie ślepe. Przeanalizowano 1018 studiów z okresu od 1 stycznia 1974 do 31 marca 2013 roku. Do metaanalizy zakwalifikowano 16 badań, badaniami objęto 3194 osób (1319 w grupie placebo, 1875 w grupie klinicznej), średni

2. Wyniki badań nad efektem placebo są publikowane co najmniej od połowy ubiegłego stulecia (por. np. Wolf S.: Effects of suggestion and conditioning on the action of chemical agents in human subjects - the phamrcology of placebos. „Journal of Clinical Investigation”, 29, 1950: 100-109), w tym artykule będą jednak cytowane wyłącznie wybrane prace opublikowane nie wcześniej niż w roku 2000. wiek badanych wynosił 13 lat, zadbano o równomierny rozkład płci w grupach. Pośród negatywnych objawów, które uznano za przejaw efektu nocebo, zgłaszano m.in.: suchość w ustach, bezsenność, częstomocz, a najczęściej bóle głowy (18\% w grupie placebo, $23 \%$ w grupie przyjmującej aktywny lek) i nudności (14\% w grupie placebo i $7 \%$ w grupie przyjmującej aktywny lek - w grupie klinicznej nie sposób oczywiście ustalić, które objawy były wynikiem przyjmowania leku, a które efektu nocebo). Ogólny wniosek uzasadniony wynikami badań brzmi: częstość działań niepożądanych leków przeciwdepresyjnych nie różni się w grupie klinicznej i placebo $[9]^{3}$.

Badania kliniczne z wykorzystaniem grupy kontrolnej poddawanej działaniu placebo potwierdziły przypuszczenie, iż pacjenci otrzymujący placebo często zgłaszają skutki uboczne, które są podobne do komunikowanych badanym w trakcie uzyskiwania świadomej zgody na przeprowadzanie badania i występujących u pacjentów z grupy poddanej działaniu badanego leku [10]. Chodzi m.in. o badania, w których łagodzono ból pacjentów dzięki zastosowaniu placebo w postaci modyfikowania samych oczekiwań tychże pacjentów $[11,12]$, efekt ten potwierdzono także (nawet - wyraźniej), badając pacjentów mających poczucie swędzenia skóry [13]. Istotny związek między oczekiwanymi przez pacjentów skutkami środków zastosowanych w terapii a ich rzeczywistym efektem został potwierdzony np. w badaniach nad opioidalnym środkiem przeciwbólowym (remifentanil): oczekiwanie przez pacjentów pozytywnego wyniku leczenia podwoiło działanie przeciwbólowe leku, natomiast negatywne nastawienie co do spodziewanej skuteczności istotnie zaburzyło działanie leku [14].

Wyniki badań, wyżej tylko bardzo wybiórczo przytoczone, potwierdzają, że oczekiwania mogą zostać uznane za najistotniejszy czynnik składający się na efekt placebo. Jednocześnie jest oczywiste, że wyjaśnianie efektu placebo tylko w kontekście oczekiwań, tj. wyłącznie na poziomie psychologicznym, jest niewystarczające. Zawsze trzeba postawić, już nie na gruncie psychologii, kolejne pytanie - jaki mechanizm neurobiologiczny leży u podłoża oczekiwań? Wyjaśnianie tego efektu na poziomie wyłącznie psychologii nie jest pełne, bo stwierdzane w psychologii prawidłowości same wymagają wyjaśnienia na gruncie innych nauk [15]. $\mathrm{W}$ badaniach laboratoryjnych nad tak uwarunkowanymi efektami placebo i nocebo - tj. korzystnymi bądź niekorzystnymi skutkami stwierdzonymi w sytuacji, gdy placebo, rozumianym jako składnik terapii było samo nastawienie, oczekiwanie na korzystne bądź niekorzystne objawy $[5,16$, 17] - wykazano, że są to zjawiska neurobiologiczne, psychobiologiczne, tj. wywoływane przez procesy psychiczne, objawiajace się w wykrywalnych zmianach ustrojowych i powodujące pozytywne/negatywne skutki zdrowotne [18, $19,20,21,22,23,11]^{4}$. Wyniki badań nad tymi efektami potwierdzają więc pogląd, iż procesy mentalne mogą aktywizować mechanizmy podobne do wywoływanych przez leki.

Niektóre badania sugerują, że na efekt placebo, zarówno w jego odmianie korzystnej, jak i niekorzystnej (nocebo), są

3. W analizowanych badaniach nie było grupy bez interwencji leczniczej i placebo, nie można zatem stwierdzić, które z działań przypisywanych efektowi nocebo, było/mogło być wynikiem samej choroby. Metaanaliza dostępnych badań nie dała odpowiedzi na to pytanie, konieczne są zatem dalsze badania w tym zakresie.

4. Psychologiczne i fizjologiczne mechanizmy efektu placebo są omówione w tekście M. Siwiak-Kobayashi [24]. 
bardziej podatne osoby starsze i z wyższym wykształceniem, a pacjenci, którzy doświadczyli objawów nadwrażliwości na leki, są w grupie zwiększonego ryzyka wystąpienia efektu nocebo [25]. Efektu placebo mogą doświadczać częściej kobiety niż mężczyźni [25], a działania niepożądane generowane przez negatywne oczekiwania mogą wpłynąć nie tylko na losy jednostek, ale i całej społeczności $[26]^{5}$.

Skoro głównym źródłem efektu placebo są nastawienia, oczekiwanie, to nie dziwi, że efekt ten jest stwierdzany w procedurach informowania pacjentów o możliwych skutków ubocznych zabiegów medycznych lub leków (samo informowanie pacjenta o możliwych skutkach ubocznych może opisane skutki wywołać, niezależnie od farmakologicznych właściwości leku [27, 28, 29, 30]). Źródła oczekiwań pacjentów co do działań ubocznych mogą się też znajdować w procesie wyrażania świadomej zgody na leczenie, w obserwacji innej osoby doświadczającej takich działań, w informacjach prezentowanych w mediach etc. [17]. Oczekiwania takie mogą być również skutkiem pozytywnej bądź negatywnej sugestii, słownej lub innej, przekazanej pacjentowi w trakcie wizyty lekarskiej [31], a szczególnie wydajnym źródłem oczekiwań i wywołanych przez nie skutków są prognozy medyczne co do przebiegu choroby i leczenia (rokowania).

\section{PODSUMOWANIE: WNIOSKI PRAKTYCZNE}

Wnioski z badań medycznych i psychologicznych nad placebo/nocebo niewątpliwie mają znaczenie dla praktyki medycznej, na pewno jednak nie można ułożyć ich w jakąkolwiek procedurę stosowalną zawsze, gdy jest stawiana prognoza lekarska. Mogą być potraktowane jedynie jako wskazania stosowalne w takiej sytuacji.

3.1. Wyniki badań nad efektem placebo, zwłaszcza w jego postaci nocebo, niewątpliwie są ważne dla etycznej strony praktyki lekarskiej. W sytuacji prognozowania medycznego rysuje się bowiem wyraźnie konflikt wartości i norm. Z jednej strony lekarze są zobowiązani do przekazywania pacjentom rzetelnych informacji o stanie ich zdrowia, niezbędnych do podjęcia przez nich świadomych i ugruntowanych dzięki tym informacjom decyzji co do leczenia [32]; z drugiej strony jednak samo przekazanie złych informacji może wzbudzić (zwykle wzbudza) spodziewanie się niekorzystnych zdarzeń,

5. Zostało to potwierdzone $\mathrm{w}$ badaniach Crichtona i in. z 2014 roku, w których badano skutki faktu, iż mieszkańcy spodziewali się problemów zdrowotnych wywołanych przez turbiny wiatrowe (w dyskusjach nad pozyskiwaniem energii z wiatru pojawia się zazwyczaj argument, że infradźwięki wytwarzane przez turbiny wiatrowe mogą powodować problemy zdrowotne u okolicznych mieszkańców). Badania wskazują na to, że ludzie spodziewający się, że środowisko ich życia sprzyja chorobom, zaczynają szukać objawów lub oznak choroby w celu potwierdzenia tych negatywnych oczekiwań, dopasowujac także objawy fizyczne różnych chorób zaobserwowane u siebie do swych negatywnych oczekiwań. W badaniach została potwierdzona hipoteza, że osoby wystawione na infradźwięki farm wiatrowych zgłaszały objawy i zmiany nastroju zarówno pozytywne, jak i negatywne, zależnie od swoich oczekiwań, a formułowane przez mieszkańców zarzuty co do niekorzystnych skutków zdrowotnych są częstsze na tych obszarach, w których rozgłos na temat szkodliwych skutków turbin jest największy. Co więcej, media, reklamy lub dyskurs społeczny o zgłoszonych skutkach zdrowotnych turbin wiatrowych dodatkowo sprzyja występowaniu podobnych objawów u innych ludzi, niezależnie od ekspozycji na dany czynnik. Badacze uważają ponadto, że ten sam efekt stwierdzić można także w innych typach problemów z zakresu ochrony środowiska i nie tylko [26]. które sprzyja ich wystąpieniu (efekt nocebo). Z obowiązkiem przekazywania rzetelnych, tj. wiarygodnych (prawdziwych) i pełnych informacji wiążą się wartości/normy prawdy i prawdomówności, poszanowania godności i autonomii pacjenta, które w sytuacji stawiania prognozy medycznej mogą się ścierać $\mathrm{z}$ wartościami i normami nieszkodzenia i dobroczynności.

Sytuacje takie są dostrzegane przez normodawców, o czym świadczy przysługujące lekarzom (warunkowe) prawo do nieprzekazywania pacjentowi złych informacji o rozpoznaniu i rokowaniu. Z prawa tego można skorzystać tylko, „jeśli lekarz jest głęboko przekonany, iż jej ujawnienie spowoduje bardzo poważne cierpienie chorego lub inne niekorzystne dla zdrowia następstwa; jednak na wyraźne żądanie pacjenta lekarz powinien udzielić pełnej informacji” [32]. Na marginesie warto zauważyć, że kryterium korzystania z tego prawa jest zawsze subiektywne.

3.2. W rzeczywistych sytuacjach formułowania prognozy wyjątkowo da się stosować zalecane w etykach zawodowych bezstronne (obiektywne) sposoby rozwiązywania konfliktów wartości i norm (np. na gruncie przyjętej hierarchii wartości i norm). Ogólna norma, by przekazywać to, co sprzyja dobru pacjenta, również jest nieskuteczna, jako że jest pozbawiona treści. Natychmiast bowiem pojawia się pytanie: „jak należy w konkretnej sytuacji (i w ogóle) rozumieć dobro pacjenta a więc wartość najczęściej wskazywaną w etyce medycznej jako najwyższą, a nawet absolutną?" Jeśli dobro obejmuje nie tylko dobry stan zdrowia, lecz także autonomię pacjenta, to $\mathrm{w}$ imię tak pojmowanego dobra powinno się i przekazywać prawdę (informacje o stanie zdrowia uznawane za prawdziwe), i unikać mówienia potencjalnie szkodliwej prawdy - a zatem konflikt pozostaje. Gdy z kolei przyjmie się zawężająco, że w kontekście medycznym dobro konkretnej osoby, tj. dobro pacjenta, powinno być utożsamiane $\mathrm{z}$ jego zdrowiem, wtedy rozwiązywanie konfliktów związanych $\mathrm{z}$ prognozowaniem (i innych) zależy od tego, jak pojmuje się zdrowie.

Rozstrzyganiu konfliktów, np. przez porównywanie ważności wartości i norm, na pewno nie sprzyja definicja zdrowia zaproponowana przez WHO, według której zdrowie to „dynamiczny dobrostan fizyczny, psychiczny, duchowy oraz społeczny, a nie tylko brak choroby czy niedomagania” [33] ${ }^{6}$. Kierując się tak rozumianym zdrowiem (czyli, w myśl tej definicji - dobrem pacjenta), obejmującym także dobrostany zakładające autonomię pacjenta, lekarz nadal może w pewnych sytuacjach przeżywać dylemat, czy przekazywać prawdę potencjalnie szkodliwą, czy też przemilczeć informacje niezbędne pacjentowi do nakreślenia i realizacji własnego planu (decydowania o sobie) - nie mówiąc o innych dylematach, pojawiających się w dążeniu do zapewnienia pacjentowi tak szeroko pojmowanego zdrowia. Wątpliwości pozostają, nawet jeśli się przyjmie, że w kontekście medycznym wartością najwyższą jest wyłącznie dobrostan fizyczny pacjenta, tj. dobre funkcjonowanie układów i narządów jego organizmu, i że zmierzaniu do tego nadrzędnego celu może towarzyszyć naruszenie innych wartości i norm, najczęściej w zakresie prawdomówności i respektowania autonomii pacjenta. Wiadomo bowiem np., że przekazanie niekorzystnych informacji o stanie zdrowia może skutkować także nadzwyczajną nieraz

6. Health is a dynamic state of complete physical, mental, spiritual and social wellbeing and not merely the absence of disease or infirmity [33]. 
mobilizacją pacjenta, sprzyjajaca pokonaniu choroby (rozumianej wąsko, tj. nie jako zaprzeczenie definicji zdrowia postulowanej przez WHO).

Dlatego decyzje lekarza co do formułowania prognozy, jej treści i sposobu przekazywania, nie mogą być proceduralne, zwykle są subiektywne i intuicyjne, oparte na wiedzy rozumianej „mądrościowo” (sokratejsko): przekazać to, co w konkretnej sytuacji lekarz uznaje za najbardziej sprzyjające subiektywnie pojmowanemu dobru konkretnego pacjenta. I tu wiec sprawdza się sentencja (przypisywana Hipokratesowi), że najlepszym lekarstwem jest dla pacjenta sam lekarz.

3.3. Wyniki badań nad efektem nocebo dostarczają dodatkowych argumentów przeciwko tezie, że ujawnianie informacji (prawdy) jest wartością samą w sobie, autoteliczną, i że bezwarunkowo służy ono autonomii i dobru/zdrowiu pacjenta. Dane z przytoczonych badań klinicznych kwestionują przydatność bezwzględnego ujawniania informacji posiadanych przez lekarzy jako niezależnego elementu świadomej zgody pacjenta, oddzielonego od analizy ryzyka i korzyści. Przeciwnie, w wielu klinicznych przypadkach, w których ryzyko efektu nocebo jest wysokie, takich jak nieinwazyjne leczenie raka, decyzja o ujawnieniu informacji powinna być, dla dobra pacjenta, w każdym indywidualnym przypadku oceniana w kontekście możliwych ryzyk i korzyści.

Z myślą o minimalizowaniu ryzyka efektu nocebo są wyrażane zastrzeżenia co do obowiązujących obecnie procedur informowania pacjenta i uzyskiwania jego świadomej zgody. Postuluje się, by w procedurach tych uwzględnić edukowanie na temat efektu nocebo zarówno pacjentów (w procesu uzyskiwania świadomej zgody), jak i lekarzy. Lekarzom zaleca się zachowanie szczególnej ostrożności w przekazywaniu pacjentom niepomyślnych informacji - m.in., by informując o potencjalnych negatywnych skutkach ubocznych, położyli nacisk na informację o procencie pacjentów dobrze tolerujących leczenie i o zdolności pacjentów do radzenia sobie z łagodnymi objawami; zaleca się im także, by rozważyli możliwość skorzystania z tego, że chory może nie chcieć uzyskać informacji o niepożądanych skutkach ubocznych.

Wykorzystanie możliwości niepoinformowania o negatywnych skutkach ubocznych dotyczy tylko łagodnych i przejściowych skutków, jak ból głowy czy wymioty. Informacje o poważnych, nieodwracalnych skutkach ubocznych muszą być oczywiście zawsze przekazane, w przeciwnym razie pacjent zostałby pozbawiony możliwości podjęcia świadomej decyzji dotyczącej swego zdrowia i życia, co niewątpliwie naruszałoby jego godność i autonomię. Konflikt ten można łagodzić, dając pacjentom listę możliwych typów skutków ubocznych i prosząc ich o wskazanie tych, które zawsze chcieliby znać przed podjęciem decyzji w sprawie przyjmowania leków, i tych, o których wolą nie wiedzieć. Postępując zgodnie z tymi zaleceniami, lekarz może przekazać pacjentowi np. następujący komunikat: „Stosunkowo niewielki odsetek pacjentów przyjmujących lek X doświadcza różnego rodzaju skutków ubocznych, które są uciążliwe, ale niezagrażające życiu ani niepowodujące poważnego upośledzenia. W oparciu o badania wiemy, że jest bardziej prawdopodobne, że pacjenci, którym lekarze opowiadają o działaniach niepożądanych leku, doświadczą tych działań częściej w porównaniu do pacjentów, którym o negatywnych skutkach ubocznych lekarze nic nie mówią. Czy chce Pan być poinformowany o tych działaniach niepożądanych leku?"[34].

Niezasadność przekazywania całej prawdy została potwierdzona także w badaniach psychologicznych nad atrybucjami (przypisywanie cech w procesach wyjaśniania zachowań i zdarzeń) i skutkami określonych atrybucji (emocjonalnymi, motywacyjnymi, zdrowotnymi etc.) oraz w praktyce psychologicznej opartej na modelach atrybucji. W teoriach atrybucji przyjmuje się założenie, że wyjaśniające uporządkowanie zdarzeń jest niezbędne dla poczucia kontroli rzeczywistości, wzbudza także pozytywne lub negatywne oczekiwania, które mogą sprzyjać adaptacji i przetrwaniu. Nie wchodząc w rozwijane od dawna, różnorodne teorie atrybucji, wykorzystamy tu podziały atrybucji na realistyczne i nierealistyczne oraz na przystosowawcze (funkcjonalne) i autodestrukcyjne (dysfunkcjonalne) [35]. Otóż lekarz lub terapeuta powinien interweniować, tj. zmieniać przekonania pacjenta, w przypadku atrybucji jednocześnie nierealistycznych i nieprzystosowawczych (autodestrukcyjnych). Gdy natomiast atrybucje są nierealistyczne, ale przystosowawcze - np. gdy pacjent wierzy, iż jakiś medycznie, a może i zdrowotnie neutralny rytuał utrzymuje go w zdrowiu - wtedy nie powinno się ingerować. To $\mathrm{z}$ jednej strony, $\mathrm{z}$ drugiej - jest oczywiste, że gdyby lekarz świadomie manipulował i próbował leczyć, bazując na efekcie placebo (gdyby utwierdzał pacjenta w nierealistycznych przekonaniach), wówczas naruszałby podstawę relacji terapeutycznej, tj. zaufanie oraz rdzeń medycyny, pojętej jako praktyka lecznicza oparta na zaufaniu.

3.4. Obok treści prognozy ważny jest także sposób jej przekazywania, zwłaszcza w przypadku skrajnie niepomyślnych dla chorego rokowań, mogących odebrać mu wolę walki i wiarę w wyzdrowienie, czyli dobre nastawienie psychiczne, którego znaczenie jest tak mocno podkreślane w holistycznym podejściu do leczenia. Jakość komunikacji z pacjentem - werbalnej i niewerbalnej - może zmniejszyć negatywne skutki procedur medycznych i przekazywanych pacjentom informacji. Aby pacjenci nie traktowali niepomyślnych prognoz lekarskich jako wyroków śmierci, lekarze powinni przede wszystkim uświadamiać im stopień niepewności stawianych przez siebie prognoz. Może w skrajnych sytuacjach prognozowania najlepszym wyjściem jest jednoznaczne przekazywanie informacji o niemożliwości postawienia przez lekarza/medycynę pewnej diagnozy? Zdjęłoby to z lekarzy nadmierny balast odpowiedzialności za stawiane przez nich diagnoz skrajnie niekorzystnych, a przy tym niepewnych i możliwie szkodliwych, pacjentom zaś pozostawiło miejsce na nadzieję i własne podejście do choroby ${ }^{7}$. Takie przekazywanie złych informacji nie tylko mniej zagraża dobru pacjenta, lecz także sprzyja zrozumieniu, uznaniu i wykorzystaniu przez pacjenta innych informacji i zaleceń istotnych dla jego stanu zdrowia.

3.5. Zrozumienie efektu nocebo prognoz medycznych uzasadnia dalsze badania dotyczące jego znaczenia klinicznego oraz - co w konkluzji tych rozważań ważne - powinno skłonić przedstawicieli zawodów medycznych do poszukiwania jakichś zawodowo i etycznie akceptowalnych wskazań co do stawiania i przekazywania prognoz, w celu zminimalizowania ich możliwego niekorzystnego wpływu na zdrowie pacjenta [34]. „Wskazań”, bo o wypracowaniu jakiejś procedury, którą dałoby się szablonowo stosować, nie może być mowy.

7. Współcześnie, zwłaszcza w środkach masowego przekazu, raczej nie wzmacnia się wiary w siły obronne organizmu i znaczenie nastawienia do choroby, stylu życia etc. - wręcz przeciwnie, wpaja się, że na wszystko potrzeba jakiejś pigułki. 
Na pewno jednak można mówić o zawarciu „przymierza terapeutycznego" między lekarzem a pacjentem, wymagającego nie tylko wymiany informacji, lecz także uczuć wywołujących określone reakcje. Jeśli w chorobie pacjent oczekuje opieki podobnej do otrzymanej w dzieciństwie, a spełnienie tego oczekiwania ma korzystne skutki lecznicze, to i w opiece medycznej prawda nie jest najważniejsza [36].

\section{PIŚMIENNICTWO}

1. Bąbel P. Placebo i nocebo. Próba integracji. Przegląd Psychologiczny $2006 ; 49(2)$ : 141-156. http://www.kul.pl/files/714/nowy_folder/ PP_2.49.2006_art.2.pdf (dostęp: 5.05.2016).

2.Shapiro A K. Semantics of the placebo. Psychiatric Quarterly 1968 42: 653-696.

3. Dolińska B. Placebo. Sopot, 2011.

4. Miller F G. Clarifying the nocebo effect and its ethical implications. The American Journal of Bioethics 2012; 12(3): 30-39.

5. Hauser W, Bartram C, Bartram-Wunn E and Tolle T. Adverse events attributable to nocebo in randomized controlled drug trials in fibromyalgia syndrome and painful diabetic peripheral neuropathy: systematic review. Clin. J. Pain 2012; 28: 437-451.

6. Colagiuri B, Zazhariae R. Patient expectancy and post-chemotherapy nausea: a meta-analysis. Ann. Behav. Med. 2010 Aug; 40(1): 3-14. http:// www.ncbi.nlm.nih.gov/pmc/articles/PMC3401955/?report=reader\#! po=45.2381 (dostęp: 1.05.2016).

7. Benedetti F, Colloca L, Torre E, Lanotte M, Melcarne A, Pesare M, Brgamasco B, Lopiano L. Placebo-responsive Parkinson patients show decreased activity in single neurons of subthalamic nucleus. Nat. Neurosci. 2004; 7: 587-588.

8. Vase L, Skyt I, Laue P G, Price D D. Placebo and nocebo effects in chronic pain patients: How expectations and emotional feelings contribute to the experience of pain. Zeitschrift für Psychologie 2004; Vol 222(3): 135-139.

9. Rojas-Mirquez JC, Rodriguez-Zuñiga MJ, Bonilla-Escobar FJ, Garcia-Perdomo HA, Petkov M, Becerra L, Borsook D, Linnman C. Nocebo effect in randomized clinical trials of antidepressants in children and adolescents: systematic review and meta-analysis. Front. Behav. Neurosci. 2014 Nov; 3(8): 375. http://www.ncbi.nlm.nih.gov/pmc/articles/ PM C4217505/ (dostęp: 1.05.2016).

10. Barsky AJ, Saintfort R, Rogers MP, Borus JF.Nonspecific medication side effects and the nocebo phenomenon. JAMA 2002; 287: 622-627.

11. Colloca L, Benedetti F, Porro CA. Experimental designs and brain mapping approaches for studying the placebo analgesic effect. Eur. J. Appl. Physiol. 2008; 102: 371-380.

12. Atlas LY, Wager TD. How expectations shape pain. Neurosci. Lett. 2012 Jun $29 ; 520(2): 140-8$.

13. Evers AW, Bartels DJ, van Laarhoven AI. Placebo and nocebo effects in itch and pain. Handb. Exp. Pharmacol. 2014; 225: 205-214.

14. Bingel U, Wanigasekera V, Wiech $\mathrm{K}$, et al. The effect of treatment expectation on drug efficacy: imaging the analgesic benefit of the opioid Remifentanil. Sci Transl Med. 2011; 3: 70-114.

15. Tomaszewski M, Ślifirczyk A, Wawryniuk P, Olchowik G, Tomaszewska M. Efekt placebo a skuteczność leczenia. Człowiek i Zdrowie 2013; 4(VII): 30-40.
16. Benedetti F, Amanzio M. Mechanisms of the placebo response. Pulm. Pharmacol. Ther. 2013; 26: 520-523.

17. Faasse K, Petrie KJ. The nocebo effect: patient expectations and medication side effects. Postgrad Med J 2013; 89: 540-546.

18. Colloca L, Miller FG. The nocebo effect and its relevance for clinical practice. Psychosomatic Medicine. 2011b; 73: 598-603.

19. Enck P, Benedetti F, Schedlowski M. New insights into the placebo and nocebo responses. Neuron 2008; 59: 195-206.

20. Benedetti F, Lanotte M, Lopiano L, Colloca L. When words are painful: unraveling the mechanisms of the nocebo effect. Neuroscience. 2007; 147: 260-71.

21. Price DD, Finniss DG, Benedetti FA. Comprehensive review of the placebo effect. Recent advances and current thought. Annu. Rev. Psychol. 2008; 59: 565-590.

22. Klosterhalfen S, Enck P. Pychobiology of the placebo response. Auton. Neurosci. 2006; 125: 94-99.

23. Colloca L, Benedetti F. Placebos and painkillers: is mind as real as matter? Nat. Rev. Neurosci. 2005; 6: 545-552.

24. Siwiak-Kobayashi M. Psychologiczne mechanizmy efektu placebo. Farmakoterapia w Psychiatrii i Neurobiologii 2000; 2: 107-113.

25. Bavbek S, Aydin O, Sözener ZC, Yüksel S. Determinants of nocebo effect during oral drug provocation tests. Allergol. Immunopathol (Madr). 2014; Jul 31. http://apps.elsevier.es/watermark/ctl_servlet? $\mathrm{f}=10$ \&pident_articulo $=0$ \&pident_usuario $=0$ \&pcontactid $=$ \&pident_re vista $=105 \&$ ty $=0$ \&accion $=$ L\&origen $=$ zonadelectura \&web $=$ zl.elsevier. es\&lan $=$ en \& fichero $=$ S0301-0546(14)00102-5.pdf\&eop $=1 \&$ early $=$ si (dostęp: 1.05.2016).

26. Crichton F, Chapman S, Cundy T, Petrie KJ. The link between health complaints and wind turbines: support for the nocebo expectations hypothesis. Front Public Health., 2014 Nov; 11(2): 220. http://www.ncbi.nlm.nih.gov/pmc/articles/PMC4227478/ (dostęp: 5.05.2016).

27. Flaten MA, Simonsen T. Olsen H. Drug-related information generates placebo and nocebo responses that modify the drug response. Psychosom Med. 1999; 61: 250-255.

28. Lancman ME, Asconape JJ, Craven WJ, Howard G, Penry JK. Predictive value of induction of psychogenic seizures by suggestion. Ann Neurol. 1994; 35: 359-61.

29. Luparello TJ, Leist N, Lourie CH, Sweet P. The interaction of psychologic stimuli and pharmacologic agents on airway reactivity in asthmatic subjects. Psychosom Med. 1970; 32: 509-513.

30. Mondaini N, Gontero P, Giubilei G, et al. Finasteride $5 \mathrm{mg}$ and sexual side effects: how many of these are related to a nocebo phenomenon? J Sex Med 2007; 4: 1708-1712.

31.van Laarhoven AIM, Vogelaar, ML, Wilder-Smith OH, van Riel PLCM, van de Kerkhof PCM, Kraaimaat FW, Evers AWM. Induction of nocebo and placebo effects on itch and pain by verbal suggestions. Pain 2011; 152(7): 1486-1494

32. Kodeks etyki lekarskiej, art. 13 oraz Ustawa z dnia 5 grudnia 1996 r. o zawodach lekarza i lekarza dentysty, art. 31: pkt 1, pkt 4.

33. News. Int. Nurs. Rev. 1998; 42(2): 36.

http://onlinelibrary.wiley.com/doi/10.1046/j.1466-7657.1998.00035.x/ epdf (dostęp 1.05.2016).

34. Colloca L, Miller FG. Role of expectations in health. Curr Opin Psychiatry 2011a; 24(2): 149-155.

35. Försterling F. Atrybucje. Podstawowe teorie, badania i zastosowanie. Gdańsk, 2005

36. Łozowski J. Efekt placebo czy efekt relacji? Sztuka Leczenia 2012; 24(1-2): 49-56. 


\title{
Placebo/nocebo effect of medical prognosis
}

\begin{abstract}
Introduction. The placebo/nocebo effect refers to the action of pharmacologically inactive substances, administered in the receptural form of prescriptions (most often pills), which is identical with the form containing therapeutic substances. This effect may be beneficial, neutral, or adverse to a patient. Interdisciplinary studies of this effect indicate the role of expectations as a psychobiological phenomenon; the results of these studies are also important for medical ethics.

Objective. To draw conclusions concerning the placebo effect which are important for medical practice.

Description of the state of knowledge. The results of empirical studies confirm that mental processes may activate mechanisms similar to those induced by medicines.

Conclusions. 1.There is a possible conflict between the need for providing a patient with true and full information (autonomy principle), and principles of nonmaleficence and beneficence. 2. Application of the methods of resolving conflicts of values and norms, recommended in professional ethics, is hampered because the term and criteria of a patientss wellbeing are unclear and blurred; and the definition of health adopted by the WHO is too broad from the practical aspect. 3 . Results of clinical tests of the nocebo effect, and also the results of psychological research on the attribution, confirm that the truth and truthfulness norms are not absolute, and in some situations it is justified not to tell a patient the whole truth, which is considered in the postulates regarding the procedures of informing patients (permissibility of not informing). 4. Good communication with a patient may decrease negative effects of medical procedures and the information provided - especially extremely unfavourable diagnoses and prognoses. 5. The consideration of the nocebo effect of medical prognosis speaks for seeking recommendations concerning informing patients of their prognoses (strict procedures are impossible), which would be both professionally and ethically accepted.
\end{abstract}

\section{Key words}

placebo, nocebo, values and norms conflict, communication with a patient, providing information about diagnosis and prognosis 